\title{
Bottom-Up Approach Ship Emission Inventory in Port of Incheon Based on VTS Data
}

\author{
Hyangsook Lee, ${ }^{1}$ Hoang T. Pham, ${ }^{1}$ Maowei Chen, ${ }^{1}$ and Sangho Choo $\mathbb{D}^{2}$ \\ ${ }^{1}$ Graduate School of Logistics, Incheon National University, Incheon 22012, Republic of Korea \\ ${ }^{2}$ Department of Urban Design \& Planning, Hongik University, Seoul 04066, Republic of Korea \\ Correspondence should be addressed to Sangho Choo; shchoo@hongik.ac.kr
}

Received 23 January 2021; Revised 24 February 2021; Accepted 19 March 2021; Published 10 April 2021

Academic Editor: Dong-Kyu Kim

Copyright $\left({ }_{0} 2021\right.$ Hyangsook Lee et al. This is an open access article distributed under the Creative Commons Attribution License, which permits unrestricted use, distribution, and reproduction in any medium, provided the original work is properly cited.

As a result of the rapid growth of international trade, atmospheric pollution from transportation has been more topical than ever, especially in dense hub port-cities. The shipping industry should pay more attention corresponding to its contribution to local atmospheric pollution. This paper supports the application of data collected from the vessel tracking service system with a bottomup approach to generate a comprehensive 2019 local ship emission inventory at Port of Incheon. The calculated emission inventory presented the dominance of $\mathrm{CO}_{2}$ emission and the considerable contribution of $\mathrm{NO}_{x}$ and $\mathrm{SO}_{x}$ emissions, the significant contribution of auxiliary engines during the hotelling at berth during the year of 2019. Then, based on calculated emission inventory, this study suggested and simulated applicable green policies in the practice: (1) local emission control area realization, (2) vessel speed reduction program, (3) application of cold ironing, and (4) establishment of a national integrated emission platform. The combination of the three first policies could help reduce the significant volume of emitted CO $(29 \%), \mathrm{NO}_{x}(30 \%)$, $\mathrm{SO}_{x}(93 \%), \mathrm{PM} 10$ and PM2.5 (64\%), VOC (28\%), $\mathrm{NH}_{3}(30 \%)$, and $\mathrm{CO}_{2}(30 \%)$.

\section{Introduction}

Transportation has been considered a remarkable contributor to atmospheric pollution [1]. The recent decades have detected a growing consideration of a leading global anthropogenic emissions contribution from in-port traffic [2]. With $90 \%$ of the global transport volume being carried by ship, maritime air pollution has exacerbated local society's health because of the high volume of emissions exhausted as well as the geographical condition. Approximately $70 \%$ of ship emissions are discharged within a radius of $400 \mathrm{~km}$ from the coastline [2]. As the result of the hub-port trend, ships often concentrate on well-located ports, where they often are situated close to busy industrial zones and densely populated cities. In-port ship emissions could supply $55-77 \%$ of total local emissions $[3,4]$. Therefore, these portcities and their hinterlands are grappling with a great burden from transport emissions and infrastructure [5]. It is estimated that approximately 230 million people, living in the top 100 world ports, are directly affected by exhaust shipping emissions [6]. Thus, the port industry has kept the momentum in green reform by reducing ship emissions and performs more of their social responsibility under higher pressure from public authorities [7, 8].

More much than it seems, it is stated that there are 450 different air pollutants which are emitted by ship engine combustion [9]. Greenhouse gases (GHGs), carbon monoxide $(\mathrm{CO})$, nitrogen oxides $\left(\mathrm{NO}_{x}\right)$, sulphur oxides $\left(\mathrm{SO}_{x}\right)$, and particulate matter (PM) are stated as key ship-source air pollutants $[10,11]$. Shipping $\mathrm{SO}_{x}$ and $\mathrm{NO}_{x}$ contribute markedly roles compared to other air pollutants in total national emissions [12]. Besides a negative affection to global climate, numerous research articles have proved a considerable negative tie between closed-to-land ship emissions and the local community's health (lead to asthma, respiratory and cardiovascular diseases, lung cancer, and premature death) [13]. Exhausted PM emissions from shipping activities are considered the main reason for the annual 60,000 cardiopulmonary and lung cancer deaths in Europe, East Asia, and South Asia littoral regions [14]. 
To reduce air pollution from ships, emission control legislations were contemplated by international regulationmaking agencies. Likewise, the International Maritime Organization (IMO) is reducing ship emission through its International Convention on the Prevention of Pollution from Ships (MARPOL) Annex VI. The sulphur content in the fuel used onboard is reduced from $3.5 \% \mathrm{~m} / \mathrm{m}$ to $0.5 \% \mathrm{~m} /$ $\mathrm{m}$ from 1 January 2020 [15]. The sulphur directive in the European Union (EU), the fourth federal standard, also called Tier 4, in the United States (U.S.), and emission control areas (ECAs) in China are promulgated to follow this regulation [16-18]. It is reported that the implementation of these regulations helped reduce $77 \% \mathrm{SO}_{x}, 23 \% \mathrm{NO}_{x}$, and 27\% PM10 emissions in the EU by 2017, compared with 2000 [19]. Despite the expected expansion in shipping, stricter emissions regulations could reduce the volume of $\mathrm{SO}_{x}$, PM2.5, and $\mathrm{NO}_{x}$ emissions by $87 \%, 92 \%$, and 56\%, respectively, between 2015 and 2050 [20].

In Korea, the public has been enhancing national air quality through its 10-year comprehensive plans since the 1990s. Air quality management basic plan during 2015-2024 is established to manage an integrated air management system. Besides, in 2017, an other comprehensive plan of particular matter management was announced with an epicenter of $30 \% \mathrm{PM}$ emission reduction and reinforcement control of the volatile organic compounds (VOCs) until 2022. [21] From December 2019, a vessel speed reduction (VSR) program has been conducted to reduce the PM level during winter in five key ports of Korea, including Port of Incheon (POI). A VSR area in each port spans $20 \mathrm{~nm}$ in radius [22]. However, almost all national policies and green measures are decided with the support of annual national emission inventories provided in the clean air policy support system (CAPSS), using national fuel supply statistics. However, these inventories revealed inconsistency and uncertainty with other local academic research articles, because of no actual traffic data [23]. Quantifying emitted emissions from shipping activities is a stride to explore the cause and scale of marine pollution [24]. It also provides valuable statistics to anticipate the future trend of pollution and then establishes counter-measures and policies [25]. Therefore, generating a more reliable in-port ship emission inventory is a pressing issue for producing appropriate regional policies and measures related to air pollutant management at ports.

In this study, a comprehensive annual ship emission inventory of target pollutants of CAPSS at POI in 2019 was estimated, according to geographical areas, operational phases, and ship types. This study applied another ship tracking system named vessel tracking service (VTS), operated by port authorities or coast guards to keep track of ship traffic and ensure navigational safety in the port area. This emission inventory applied a bottom-up approach with both EO and FC methods to see the difference in the estimating results of the two methods and then achieved a comprehensive multidimensional understanding of air pollutants from in-port ship operation. Then, applicable green policies for the POI situation in the practice will be suggested and simulated to evaluate their effects based on the calculated emission inventory. The remainder of this study is grouped as follows: Section 2 summarizes the previous studies related to ship-related emissions and then points out the research demand of this paper. Materials preparation is introduced in Section 3. Section 4 describes two applied methodologies for ship emission prediction. Section 5 presents and discusses calculation results. Several policies to reduce the volume of emissions emitted from ships operated at POI are suggested and simulated in Section 6 and Section 7 is the conclusion of this study.

\section{Literature Review}

Numerous previous studies have suggested estimation methods to generate ship emissions. The mainstream methods to prepare ship emission inventory can be broadly categorized into two main approaches: top-down approach (fuel-based) and bottom-up approach (activity-based). In the top-down approach, exhausted ship emissions are estimated from analyzed statistically marine fuel sales and fuel-related emission factors [26]. The marine fuel sale reports are mainly published by the Energy Information Administration, the International Energy Agency, and the United Nations Framework Convention on Climate Change [27]. This approach is recommended for a low level of traffic data availability situation. Due to the positive correlation between fuel consumption and emissions discharged from engine combustion, this approach would be the most accurate method if researchers could be confident about the marine fuel sales data collected. However, it proved that there is a significant discrepancy between banker fuel sales statistics and the actual fuel used by the global fleets [28]. The main reasons behind this difference could be the practice of offshore tinkering or the inaccurate fuel statistics in several countries [27].

Due to difficulties in collecting reliable inputs for the top-down approach, the bottom-up approach is recommended as another choice if accurate sailing statistics (e.g., actual travel distance with speed and port calling records with real-time operations) are available. Also, this method requires a higher level of input parameters such as detailed ship technical data (e.g., ship types, engine characteristics, and design information). An amount of emitted emissions is calculated for each specific ship activity and then scaled up over activities and trips to figure out the total volume of emissions [29]. The generic emission estimation equation of bottom-up can be expressed in the following equation:

$$
E=\text { Energy.EF (.CF), }
$$

where $E$ is the emission amount of certain pollutants from the ship's engines; Energy is the energy demand; EF is the emission factor; and CF is a controlling factor used when the ship is equipped with reduction technologies or fuel correction factors. In general, the estimation of energy demand can be dichotomized into the following:

(a) The total energy output (EO) of operated engines during the operating time, by applying the following equation: 


$$
\text { Energy }=\text { P.LF.T } \text {. }
$$

(b) The total engines' fuel consumption (FC) during the operating time, using the following equation:

$$
\text { Energy }=\text { SFOC (.LF).T, }
$$

where $P$ denotes engine power; $L F$ denotes load factor; $T$ denotes activity time; and SFOC denotes specific fuel consumption.

Bottom-up approach ship-related emission studies since 2009 are summarized in Table 1. As shown in Table 1, the EO method dominated the bottom-up approach for estimating ship-related emissions, especially from 2014. The most considered pollutants in previous studies are $\mathrm{CO}_{2}, \mathrm{NO}_{x}, \mathrm{CO}$, $\mathrm{SO}_{x}$, and $\mathrm{PM}$.

It is widely agreed that the bottom-up approach is generally more accurate than the former [52]. Therefore, over the last two decades, the latter has been adopted frequently by researchers [26]. Inaccuracy estimation from the top-down approach at the national level could lead to a completely different understanding and measures at the regional air quality management level. Therefore, at the regional level, the bottom-up approach is recommended to be a reliable source to establish effective green policies for better air condition [40, 53, 71, 72]. However, for larger scales, applications of the bottom-up approach have been finite because of data gaps and anomalies [52, 54]. Also, the diversity and details in input information could help improve the reliability of results; however, its corresponding complexity also increases the level of uncertainty, which is associated with the different applied models and assumptions, and how to collect the set of inputs [27, 29]. Especially, on a global scale, the use of average input parameters such as different load factors, operational activity time, and emission factors for a different size, age, and type of ships leads to considerable uncertainty in estimation $[54,73]$.

Recently, a vessel tracking system named automatic identification system (AIS), proposed in the IMO International Convention of Safety of Life at Sea (SOLAS) for better identification of ships, has been widely applied in the stream to enhance estimations $[44,46,49,51,52,56,74]$ and considered as "the best method to report the activities and movements of ships" [26]. This system is equipped compulsively on passenger ships of all sizes and commercial ships with 300 gross tonnage (GT) or more operated at sea. Therefore, high-resolution ship movement AIS data could be a fount of reliable relative ship operational profile as vessel travel time and average speed between waypoints on the sea at short-time intervals and identify ship routes. Also, AIS collects and transmits ship characteristics as IMO identification number, size, weight, etc. [52]. Hence, ship's activities are better geographically characterized and analyzed, and consequently, it improves the reliability of emission inventory investigation. Despite the abovementioned benefits, the AIS system does not cover ships with less than $300 \mathrm{GT}$. Besides, with ships greater than or equals to $300 \mathrm{GT}$, in several cases, AIS data could not be fully accessible. Time gaps also occur in several cases if temporary signal disruption happens, resulting in erroneous position reports.

During the last decades, several investigations about Korean port-related ship emissions have been conducted domestically. At the national level, under CAPSS, national air pollutants emission inventories, including in-port ship emissions, had been updated annually, and the latest update is for the year 2016 [75]. However, CAPSS only considers hotelling at anchorage and berth and maneuvering process in port emission. The equations with values of parameters, provided by NIER [76], follow a top-down approach based on fuel consumption and are shown in the following equations:

$$
\begin{aligned}
E & =\sum_{\mathrm{ph}} \mathrm{FC}_{\mathrm{ph}} \times \mathrm{EF}, \\
\mathrm{FC}_{\text {hotelling }} & =N \times \mathrm{DF} \times 0.79 \times 0.2, \\
\mathrm{FC}_{\text {manoeuvring }} & =\frac{\sum(2 \times N \times D)}{\mathrm{FE}},
\end{aligned}
$$

where FC represents fuel consumption; $\mathrm{N}$ represents annual total ship call; DF is average daily fuel consumption by ship type (ton/day); $D$ represents average travel distance in port $(\mathrm{km})$; FE represents average fuel economy by ship tonnage $(\mathrm{km} / \mathrm{kL}) ; 0.79$ is the average hotel time of a ship call per day; and 0.2 means the fuel consumption of hotelling at anchorage and berth will be assumed as $20 \%$ of the fuel consumption of full operation.

At the regional level, Shin and Cheong [39] generated the GHGs ship emissions at Port of Busan (POB) with a topdown approach. Chang et al. [44] firstly used the bottom-up approach to assess the GHGs emissions from ship operations at the Port of Incheon (POI) from January to October 2012 based on the FC method. Later, Chang et al. [49] continued to apply the FC method to update $\mathrm{NO}_{x}, \mathrm{SO}_{x}$, and $\mathrm{PM}$ emissions released from ships at POI during the same period. With the same method, Khan et al. [61] collected ship traffic data at POI from the AIS system to figure out ship GHG emissions, however, during only October 2014. Kwon et al. [1] developed a system for emission estimation and then considered the amount of $\mathrm{CO}, \mathrm{NO}_{x}, \mathrm{SO}_{x}$, and PM10 emitted from ships around POI only in December 2017. Lee et al. [70] estimated a non- $\mathrm{CO}_{2}$ emission inventory in POI during 2017 using VTS data and the EO method.

This paper supports the idea of the application of VTS data in the bottom-up approach studies as a promising confident alternative suggested by Lee et al. [70]. However, the contribution of this paper is that

(1) On one face, this paper considers an FC method, which was used to estimate emissions in POI several times before by Chang et al. [44], Chang et al. [49], and Khan et al. [61]. However, all of these three papers did not provide an up-to-date and full-year estimation. On the other hand, this paper also considers the EO method applied by Lee et al. [70]; however, this paper investigates additionally $\mathrm{CO}_{2}$ emission, which is the most important pollutant but 
TABLE 1: Summary of bottom-up approach studies.

\begin{tabular}{|c|c|c|c|c|}
\hline Author & Method & Operation modes & Considered pollutants & $\begin{array}{c}\text { General estimating } \\
\text { equation }\end{array}$ \\
\hline Kwon et al. [1] & $\mathrm{EO}$ & Cru, Man, Hot & \multirow{2}{*}{$\begin{array}{c}\mathrm{NO}_{\mathrm{x}}, \mathrm{CO}, \mathrm{SO}_{\mathrm{x}}, \mathrm{PM} 10 \\
\mathrm{NO}_{\mathrm{x}}, \mathrm{CO}, \mathrm{SO}_{\mathrm{x}}, \mathrm{CO}_{2}, \mathrm{CH}_{4}, \mathrm{~N}_{2} \mathrm{O}, \mathrm{HC}, \mathrm{PM} 10 \\
\mathrm{PM} 2.5\end{array}$} & $\mathrm{E}=\mathrm{P} . \mathrm{LF} . \mathrm{T} . \mathrm{EF}$ \\
\hline Song [2] & $\mathrm{EO}$ & Cru, Man, Hot & & $\mathrm{E}=\mathrm{P} . \mathrm{LF} . \mathrm{T} . \mathrm{EF} . \mathrm{CF}$ \\
\hline Sanabra et al. [5] & $\mathrm{EO}$ & Cru, Man, Hot & \multirow{3}{*}{$\begin{array}{c}\mathrm{SO}_{2}, \mathrm{PM} 2.5, \mathrm{NO}_{\mathrm{x}}, \mathrm{VOCs} \\
\mathrm{CH}_{4}, \mathrm{CO}, \mathrm{CO}_{2}, \mathrm{NO}_{\mathrm{x}}, \mathrm{PM} 10, \mathrm{PM} 2.5, \mathrm{SO}_{\mathrm{x}} \\
\mathrm{NO}_{\mathrm{x}}, \mathrm{CO}, \mathrm{SO}_{\mathrm{x}}, \mathrm{NMVOC}, \mathrm{TSP}, \mathrm{PM} 10 \\
\mathrm{PM} 2.5, \ldots\end{array}$} & $\mathrm{E}=\mathrm{P} . \mathrm{LF} . \mathrm{T} . \mathrm{EF}$ \\
\hline Merk [6] & $\mathrm{EO}$ & Cru, Man, Hot & & $\mathrm{E}=\mathrm{P} . \mathrm{LF} . \mathrm{T} . \mathrm{EF}$ \\
\hline EEA [12] & $\mathrm{EO}$ & Cru, Man, Hot & & $\mathrm{E}=\mathrm{P} . \mathrm{LF} . \mathrm{T} . \mathrm{EF}$ \\
\hline Song and Shon [23] & $\mathrm{EO}$ & Cru, Man, Hot & \multirow{2}{*}{$\begin{array}{c}\mathrm{SO}_{2}, \mathrm{NO}_{\mathrm{x}}, \mathrm{CO}_{2}, \mathrm{VOC}, \mathrm{PM} \\
\mathrm{NO}_{\mathrm{x}}, \mathrm{CO}, \mathrm{SO}_{\mathrm{x}}, \mathrm{CO}_{2}, \mathrm{HC}, \mathrm{CH}_{4}, \mathrm{PM} 10, \mathrm{PM} 2.5 \\
\mathrm{~N}_{2} \mathrm{O}\end{array}$} & $\mathrm{E}=\mathrm{P} . \mathrm{LF} . \mathrm{T} . \mathrm{EF}$ \\
\hline ICF International [30] & $\mathrm{EO}$ & Cru, Dec, Man, Hot & & $\mathrm{E}=\mathrm{P} . \mathrm{LF} . \mathrm{T} . \mathrm{EF}$ \\
\hline Corbett et al. [31] & FC & $\mathrm{N} / \mathrm{a}$ & $\mathrm{CO}_{2}$ & $\mathrm{E}=$ SFOC. LF. T. EF \\
\hline Joseph et & $\mathrm{EO}$ & Cru, Man, Hot & $\mathrm{NO}_{\mathrm{x}}, \mathrm{SO}_{2}, \mathrm{TSP}, \mathrm{PM} 10$ & $\mathrm{E}=\mathrm{P} . \mathrm{LF} . \mathrm{T} . \mathrm{EF}$ \\
\hline Deniz and Kilic [33] & FC & Cru, Man, Hot & $\mathrm{NO}_{\mathrm{x}}, \mathrm{SO}_{2}, \mathrm{CO}, \mathrm{CO}_{2}, \mathrm{VOC}, \mathrm{PM}$ & $\mathrm{E}=$ SFOC. $\mathrm{T} . \mathrm{EF}$ \\
\hline Deniz et al. [34] & $\mathrm{EO}$ & Cru, Man, Hot & $\mathrm{NO}_{\mathrm{x}}, \mathrm{SO}_{2}, \mathrm{CO}_{2}, \mathrm{HC}, \mathrm{PM}$ & $\mathrm{E}=\mathrm{P} . \mathrm{LF} . \mathrm{T} . \mathrm{EF}$ \\
\hline Howitt e & FC & $\mathrm{N} / \mathrm{a}$ & $\mathrm{CO}_{2}$ & $\mathrm{E}=\mathrm{P}$. LF. SFOC. T. EF \\
\hline Kiliç and Deniz [36] & $\mathrm{EO}$ & Cru, Man, Hot & $\mathrm{NO}_{\mathrm{x}}, \mathrm{SO}_{2}, \mathrm{CO}_{2}, \mathrm{HC}, \mathrm{PM}$ & $\mathrm{E}=\mathrm{P} . \mathrm{T} . \mathrm{EF}$ \\
\hline Lonati et al. [37] & $\mathrm{FC}$ & Man, Hot & $\mathrm{NO}_{\mathrm{x}}, \mathrm{SO}_{\mathrm{x}}, \mathrm{CO}, \mathrm{VOC}, \mathrm{PM} 10$ & $\mathrm{E}=$ SFOC. T. EF \\
\hline Tzannatos [38] & $\mathrm{EO}$ & Man, Hot & $\mathrm{NO}_{\mathrm{x}}, \mathrm{SO}_{2}, \mathrm{PM}$ & $\begin{array}{c}E=\text { P. LF. T. EF } \\
\text { Man: } E=D . F^{-1 .} E F\end{array}$ \\
\hline Shin and Cheong [39] & FC & Man, Hot & $\mathrm{CO}_{2}, \mathrm{~N}_{2} \mathrm{O}, \mathrm{CH}_{4}$ & $\begin{array}{c}\text { Hot: } \mathrm{E}=(\text { FC. } 0.2) \cdot 0.79 . \\
\mathrm{EF}\end{array}$ \\
\hline Villalba and Gemechu [40] & $\mathrm{EO}$ & Man, Hot & $\mathrm{CO}_{2}$ & $\mathrm{E}=\mathrm{P} . \mathrm{LF} . \mathrm{T} . \mathrm{EF}$ \\
\hline Cha & FC & Dec & $\mathrm{NO}_{\mathrm{x}}, \mathrm{SO}_{2}, \mathrm{CO}_{2}, \mathrm{HC}, \mathrm{PM}$ & $\mathrm{E}=$ SFOC. LF. T. EF \\
\hline Berechman and Tseng [42] & $\mathrm{EO}$ & Hot & $\mathrm{NO}_{\mathrm{x}}, \mathrm{CO}, \mathrm{SO}_{2}, \mathrm{CO}_{2}, \mathrm{HC}, \mathrm{VOC}, \mathrm{PM} 10, \mathrm{PM} 2.5$ & $\mathrm{E}=\mathrm{P} . \mathrm{LF} . \mathrm{T} . \mathrm{EF}$ \\
\hline al. [43] & $\mathrm{EO}$ & Cru, Dec, Man, Hot & $\mathrm{NO}_{\mathrm{x}}, \mathrm{SO}_{2}, \mathrm{PM} 10$ & $\mathrm{E}=\mathrm{P} . \mathrm{LF} . \mathrm{T} . \mathrm{EF}$ \\
\hline Chang et al. [44] & FC & Cru, Man, Hot & $\mathrm{CO}_{2}$ & $\mathrm{E}=\mathrm{SFC} . \mathrm{LF} . \mathrm{T} . \mathrm{EF}$ \\
\hline nd Osland [45] & $\mathrm{EO}$ & ec, Man, Hot & $\mathrm{NO}_{\mathrm{x}}, \mathrm{SO}_{2}, \mathrm{PM} 10$ & $\mathrm{E}=\mathrm{P} . \mathrm{LF} . \mathrm{T} . \mathrm{EF}$ \\
\hline $\mathrm{Ng} \epsilon$ & EO & Cru, Dec, Man, Hot & $\mathrm{SO}_{2}, \mathrm{NO}_{\mathrm{x}}, \mathrm{CO}, \mathrm{VOC}, \mathrm{PM} 10$ & $\mathrm{E}=\mathrm{P} . \mathrm{LF} . \mathrm{T} . \mathrm{EF}$ \\
\hline Saraçoğlu et al. [47] & $\mathrm{EO}$ & Cru, Man, Hot & $\mathrm{NO}_{\mathrm{x}}, \mathrm{SO}_{2}, \mathrm{CO}_{2}, \mathrm{HC}, \mathrm{PM}$ & $\mathrm{E}=\mathrm{P} . \mathrm{LF} . \mathrm{T} . \mathrm{EF}$ \\
\hline Tai and Lin [48] & $\mathrm{FC}$ & Cru, Man, Hot & $\mathrm{NO}_{\mathrm{x}}, \mathrm{SO}_{2}, \mathrm{CO}_{2}, \mathrm{HC}, \mathrm{PM}$ & $\mathrm{E}=\mathrm{T} . \mathrm{FE} . \mathrm{EF}$ \\
\hline I. [49] & FC & Cru, Man, Hot & $\mathrm{NO}_{\mathrm{x}}, \mathrm{SO}_{2}, \mathrm{PM}$ & $\mathrm{E}=$ SFC. $\mathrm{LF} . \mathrm{T} . \mathrm{EF}$ \\
\hline Liu et al. [50] & $\mathrm{FC}, \mathrm{EO}$ & Man, Hot & $\mathrm{SO}_{2}$ & $\mathrm{E}=\mathrm{FC} . \mathrm{EF}$ \\
\hline \multicolumn{5}{|l|}{$\mathrm{E}=\mathrm{P} . \mathrm{LF} . \mathrm{T} . \mathrm{EF} . \mathrm{CF}$} \\
\hline $\begin{array}{l}\text { Goldsworthy and Goldsworthy } \\
\text { [51] }\end{array}$ & $\mathrm{EO}$ & Cru, Man, Hot & $\begin{array}{c}\mathrm{NO}_{\mathrm{x}}, \mathrm{CO}, \mathrm{SO}_{2}, \mathrm{CO}_{2 \mathrm{e}}, \mathrm{PAH}, \mathrm{VOC}, \mathrm{PM} 10 \\
\mathrm{PM} 2.5\end{array}$ & $\mathrm{E}=\mathrm{P} . \mathrm{LF} . \mathrm{T} . \mathrm{EF}$ \\
\hline Coello et al. [52] & $\mathrm{EO}$ & $\mathrm{N} / \mathrm{a}$ & $\mathrm{CO}_{2}, \mathrm{NO}_{\mathrm{x}}, \mathrm{CO}, \mathrm{NMVOC}, \mathrm{SO}_{\mathrm{x}}, \mathrm{PM}$ & $\mathrm{E}=\mathrm{P} . \mathrm{LF} . \mathrm{T} . \mathrm{EF}$ \\
\hline Tichavska and Tovar [53] & $\mathrm{EO}$ & Cru, Man, Hot & $\mathrm{CO}_{2}, \mathrm{NO}_{\mathrm{x}}, \mathrm{CO}, \mathrm{SO}_{\mathrm{x}}, \mathrm{PM} 2.5$ & $\mathrm{E}=\mathrm{P} . \mathrm{LF} . \mathrm{T} . \mathrm{EF}$ \\
\hline Maragkogianni et al. [54] & $\mathrm{EO}$ & Man, Hot & $\mathrm{NO}_{\mathrm{x}}, \mathrm{SO}_{\mathrm{x}}, \mathrm{PM}$ & $\mathrm{E}=\mathrm{P} . \mathrm{LF} . \mathrm{T} . \mathrm{EF}$ \\
\hline Cullinane et al. [55] & $\mathrm{EO}$ & Man, Hot & \multirow{2}{*}{$\begin{array}{c}\mathrm{NO}_{\mathrm{x}}, \mathrm{CO}, \mathrm{SO}_{2}, \mathrm{CO}_{2}, \mathrm{HC}, \mathrm{PM} 10, \mathrm{PM} 2.5 \\
\mathrm{NO}_{\mathrm{x}}, \mathrm{CO}, \mathrm{SO}_{2}, \mathrm{NMVOC}, \mathrm{PM} 10, \mathrm{PM} 2.5, \mathrm{OC}, \\
\text { EC, } \mathrm{V}, \mathrm{Ni}\end{array}$} & $\mathrm{E}=\mathrm{P} . \mathrm{LF} . \mathrm{T} . \mathrm{EF}$ \\
\hline Fan et al. [56] & $\mathrm{EO}$ & N/a & & $\mathrm{E}=\mathrm{P} . \mathrm{LF} . \mathrm{T} . \mathrm{EF} \cdot \mathrm{CF}$ \\
\hline & $\mathrm{EO}$ & 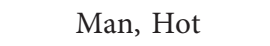 & $\mathrm{NO}_{x}, \mathrm{SO}_{2}, \mathrm{PM} 2.5$ & $\mathrm{E}=\mathrm{P} . \mathrm{LF} . \mathrm{T} . \mathrm{EF}$ \\
\hline [58] & $\mathrm{EO}$ & Cru, Man, Hot & $\mathrm{NO}_{\mathrm{x}}, \mathrm{CO}, \mathrm{SO}_{2}, \mathrm{HC}, \mathrm{PM} 10, \mathrm{PM} 2.5$ & $\mathrm{E}=\mathrm{P} . \mathrm{LF} . \mathrm{T} . \mathrm{EF} . \mathrm{CF}$ \\
\hline [59] & $\mathrm{EO}$ & Cru, Dec, Man, Hot & $\mathrm{CO}_{2 \mathrm{e}}$ & $\mathrm{E}=\mathrm{P} . \mathrm{LF} . \mathrm{T} . \mathrm{EF}$ \\
\hline Alver et al. [7] & $\mathrm{EO}$ & Cru, Man, Hot & $\mathrm{NO}_{\mathrm{x}}, \mathrm{SO}_{2}, \mathrm{HC}, \mathrm{PM} 10$ & $\mathrm{E}=\mathrm{P} . \mathrm{LF} . \mathrm{T} . \mathrm{EF}$ \\
\hline Knežević et al. [60] & $\mathrm{EO}$ & Man, Hot & $\mathrm{NO}_{\mathrm{x}}, \mathrm{SO}_{\mathrm{x}}, \mathrm{VOC}, \mathrm{PM}$ & $\mathrm{E}=\mathrm{P} . \mathrm{LF} . \mathrm{T} . \mathrm{EF}$ \\
\hline Khan et al. [61] & FC & Cru, Man, Hot & $\mathrm{CO}_{2}$ & $\mathrm{E}=\mathrm{SFC} . \mathrm{LF} . \mathrm{T} . \mathrm{EF}$ \\
\hline 1. [62] & $\mathrm{EO}$ & Cru, Dec, Man, Hot & $\mathrm{NO}_{\mathrm{x}}, \mathrm{CO}, \mathrm{HC}, \mathrm{CO}_{2}$ & $\mathrm{E}=\mathrm{P} . \mathrm{LF} . \mathrm{T} . \mathrm{EF}$ \\
\hline Cao & $\mathrm{EO}$ & Cru, Man, Hot & $\mathrm{NO}_{\mathrm{x}}, \mathrm{CO}, \mathrm{SO}_{2}, \mathrm{CO}_{2}, \mathrm{HC}, \mathrm{PM} 10, \mathrm{PM} 2.5$ & $\mathrm{E}=\mathrm{P} . \mathrm{LF} . \mathrm{T} . \mathrm{EF} . \mathrm{CF}$ \\
\hline Zhang et al. [64] & $\mathrm{EO}$ & $\begin{array}{c}\text { Cru, Dec }+ \text { Man, } \\
\text { Hot }\end{array}$ & $\mathrm{NO}_{\mathrm{x}}, \mathrm{CO}, \mathrm{SO}_{\mathrm{x}}, \mathrm{CO}_{2}, \mathrm{HC}, \mathrm{PM} 10, \mathrm{PM} 2.5$ & $\mathrm{E}=\mathrm{P} . \mathrm{LF} . \mathrm{T} . \mathrm{l}$ \\
\hline Ivce et al. [65] & $\mathrm{EO}$ & Cru, Man, Hot & \multirow{4}{*}{$\begin{array}{c}\mathrm{CO}_{2} \\
\mathrm{SO}_{\mathrm{x}}, \mathrm{NO}_{\mathrm{x}}, \mathrm{PM} 10 \\
\mathrm{SO}_{\mathrm{x}}, \mathrm{CO}_{2}, \mathrm{VOC}, \mathrm{PM} \\
\mathrm{NO}_{\mathrm{x}}, \mathrm{CO}, \mathrm{SO}_{\mathrm{x}}, \mathrm{CO}_{2}, \mathrm{HC}, \mathrm{CH}_{4}, \mathrm{NMVOC} \\
\mathrm{PM} 10, \mathrm{PM} 2.5\end{array}$} & $\mathrm{E}=\mathrm{P} . \mathrm{LF} . \mathrm{T} . \mathrm{EF}$ \\
\hline Wan et al. [66] & $\mathrm{EO}$ & Cru, Dec, Man, Hot & & $\mathrm{E}=$ P. LF. T. EF. CF \\
\hline Stazić et al. [67] & $\mathrm{EO}$ & Cru, Man, Hot & & $\mathrm{E}=\mathrm{P} . \mathrm{LF} . \mathrm{T} . \mathrm{EF}$ \\
\hline al. $[68]$ & $\mathrm{EO}$ & Cru, Dec, Man, Hot & & $\mathrm{E}=$ P. LF. T. EF. CF \\
\hline et al. [69] & $\mathrm{EO}$ & . & $\mathrm{CO}, \mathrm{CO}_{2}, \mathrm{NO}_{\mathrm{x}}, \mathrm{SO}_{2}, \mathrm{PM}, \mathrm{VOC}$ & $\mathrm{E}=\mathrm{P} . \mathrm{LF} . \mathrm{T} . \mathrm{EF}$ \\
\hline Lee et al. [70] & $\mathrm{EO}$ & Cru, Man, Hot & $\mathrm{CO}, \mathrm{NO}_{\mathrm{x}}, \mathrm{SO}_{\mathrm{x}}, \mathrm{PM}, \mathrm{VOC}, \mathrm{NH}_{3}$ & $\mathrm{E}=\mathrm{P} . \mathrm{LF} . \mathrm{T} . \mathrm{EF}$ \\
\hline
\end{tabular}


was not considered by Lee et al. [70]. Then, the paper compares the results from the two methods to figure out the gap between them. Hence, it provides a comprehensive annual ship emission inventory by different calculating methods, which covers all ships operated at the port during all months in one calendar year as well as focuses on all key pollutants of CAPSS [77]: $\mathrm{CO}_{2}, \mathrm{CO}, \mathrm{NO}_{x}, \mathrm{SO}_{x}, \mathrm{PM}$ (including PM10 and PM2.5), VOCs, and ammonia $\left(\mathrm{NH}_{3}\right)$;

(2) This paper suggests several available policy implications to reduce the local ship-related emissions and then simulated the effects of them if they will be conducted in the future.

\section{Materials Preparation}

3.1. Geographical Scope. Incheon metropolitan city is South Korea's third most populous city after Seoul and Busan and also is the gateway of the northwestern area and Seoul capital area, the world's fourth-largest metropolitan area by population, with the Yellow Sea. After becoming an international port in 1883, POI has been the country's logistics hub that handles and distributes both general cargoes and containers. It is ranked as the global $27^{\text {th }}$ busiest port in terms of cargo volume and the $50^{\text {th }}$ biggest container port [78]. Currently, POI has expanded into 125 berths, with a total of 26,031 meters of berth length, distributed to five main component ports as North Port, Inner Port, Coastal Port, South Port, and New Port. The North Port is an industrial port specialized in managing raw materials as scrap iron, feed-by products, hardwood, etc. With a lock-gate, a calm water level in the Inner Port is available for handling semiconductor equipment, automobiles, and precision machine parts. It also is a multipurpose port that serves other cargoes as grain, fruit, and general cargo. The South Port is available for handling small and medium containers and general cargoes. The New Port is under-constructed and specialized for handling medium and large containers. The Coastal Port, with international passenger and ferry terminals, focuses on serving passenger cruise ships and car ferries. Also, around these component ports, POI operates three smaller specialized ports named Geocheom-do Port, Song-do Port, and Yeongheung-do Port. The Song-do Port is specialized in fossil energy products, while the Geocheom-do Port is used for handling sand. The Yeongheung-do Port is constructed to support Yeongheung Thermal Power Plants. The capacity of POI is described in Table 2.

The POI geographical segments are presented in Figure 1 . The study not only covered ship operation inside the port boundary but also the "affected zone" (within $5 \mathrm{~km}$ from the port boundary) to consider the effect of close-toport emitted ship emissions, following EPA [80].

3.2. Activity Phase. A typical ship call often contains consecutive activity phases, which consist of a series of continuous activities that have similar features, categorized as "cruising, "maneuvering," "hotelling at anchorage," and "hotelling at berth." Due to the VSR program was applied for a few last days in December 2019, the "decelerating phase" is assumed as not considered in this study. As defined in ICF [30] and by Song [2], at the "cruising" phase, the ship moves inside the port boundary, and all engines keep running. "Maneuvering" is the time that the ship transits between the breakwater (intersection of open sea and inland waterway) and berths at a slower speed. Even with tug assist, the propulsion engines are still in operation. "Hotelling at anchorage" is a period of waiting for berth call while "hotelling at berth" is the time that ships are docking at berth. In both "hotelling at anchorage" and "hotelling at berth" phases, only auxiliary engines (including boilers) still work with a peak load for providing on-board power. In the "hotelling at berth" phase, the ship can use shore power instead of turning on auxiliary engines, called cold ironing; however, cold ironing has been still not implemented in POI yet. The average speed and travel distance in each phase were provided by a local pilot company. Table 3 summarizes detailed activity phases information in POI.

3.3. Ship Classification. Ship characteristics (e.g., speed, engine size, and usage) vary considerably depending on the ship type. Previous studies classified ships in different ways; however, the common standard applied is a type of cargoes carried on the ship. This study followed ICF's classification with 11 types of ships [30]. However, in POI, there are eight types available, involving bulk carrier, container ship, cruise ship, general cargo, reefer, roll-on/roll-off (RORO), tanker, and miscellaneous.

\subsection{Data Collection and Analysis}

3.4.1. Data Source. Due to the limitations of the AIS system mentioned above, in this study, in-port ship traffic data were collected from the VTS-based Korean Port Management Information System (Port-MIS) to consider ships with GT less than 300. A total of 16,677 ship calls were recorded from Port-MIS, as shown in Table 4. Tanker fleet dominated ship calls at POI in 2019 with $42.6 \%$ of the total ship calls, following by the general cargo fleet and container ship fleet with $20.2 \%$ and $17.3 \%$, respectively. Reefer fleet only contributed negligibly to total ship calls with $0.02 \%$ of total ship calls.

3.4.2. Data Cleaning and Make-Up. A total of 47,626 statuses describing the entire marine traffic at POI during 2019 were collected. These statuses were noted in order of occurrence inside POI, which is different from the ship call's timeline format. Two consecutive events in the same ship call usually are several hours apart; then, a ship call can last from a few hours to a few days. Also, a high level of traffic exaggerated the complexity level of the original data and made it an arduous task to handle nagging details. Therefore, a code, combined from call sign and time points, was applied to resort original data corresponding to the timeline of each ship call. 
Waypoints are used to present ship activities in data. A typical ship call contains waypoints as (1) entrance, clearance from the port area; (2) anchoring, collecting anchor; (3) berthing, unberthing; and (4) shift within the port area between berths (if need). A combination of two consecutive waypoints identifies a corresponding activity phase of the ship call. The time information of each waypoint is provided in the YYYY/MM/DD HH: MM format. The time of an activity phase is identified as the subtractions of 2 corresponding waypoints' time. The average moving time and distance of the cruising and maneuvering process for each target port were calculated. In several cases, when only arrival and departure times were reported in the data, the total time of ship spent on the port is the difference between arrival time and departure time. Later, the corresponding average moving time and distance for the target port are applied, and then the hotelling time at the berth of that ship is the subtraction of average cruising and maneuvering time from the total time.

3.4.3. Ship Basic Data. Basic information about the ship, involving name, ship type, engine type, propulsion engine power, weight tonnage, and design speed, was obtained from the Korea Ship Safety Technology Authority and Korean Register. For missing propulsion engine power data, a simple linear approach to modeling the relationship between ship weight tonnage and propulsion engine power is applied by ship types. Linear models are shown in Figure 2. The coefficients of determination $\left(R^{2}\right)$ are relatively high $(>0.85)$, showing the high reliability of prediction.

Besides, installed auxiliary engine power also was not collected completely because there is a lack of information from manufacturers. However, it is impossible to apply a linear approach to estimate auxiliary engine power because there is no connection between installed auxiliary engine power and speed [51]. Also, it is difficult to recognize the using level of auxiliary engines in each activity phase during a ship call in the practice. Therefore, in previous studies, installed auxiliary engine power is commonly estimated by applying the default ratios by ship types with the total propulsion engine power of the ship [51]. This study applied the ratios revised from ICF [30], which is shown in Table 5.

Lastly, the real values of revolutions per minute (RPM) of engines also were obtained from the Korea Ship Safety Technology Authority and Korean Register. RPM value of the engine helps to classify those engine speed designations: high-speed diesel (HSD), medium-speed diesel (MSD), and slow-speed diesel (SSD). Then, based on engine speed designations, proper EF values are matched in the calculation. In the case of missing values, they were made up of average values, as shown in Table 6 .

3.4.4. Activity Time. The ship transit time was calculated with the actual speed of the ship and the representative travel distance of each port (from border to berth). The average transit time by the port is shown in Table 7. Among ports in POI, Inner Port shows the largest value because of a lockgate.
The actual times in hotelling at anchorage and berth were obtained from the difference in time between anchoring, collecting anchor, and berthing, unberthing. To avoid anomalies, the ceilings are applied as 7 days (168 hours) for hotelling at anchorage and 14 days (336 hours) for hotelling at berth. The average docking time by ship type after applying ceilings is shown in Table 8 . Almost average values by ship type (except container ship's average time) are considerably greater than the national average time applied in CAPSS (0.79 days 18.96 hours). These differences may lead to considerable variances between estimated results and national estimations, especially tankers, general cargo ships, and container ships dominated the total number of ship calls at POI with the north of $80 \%$.

\section{Methodology}

To provide a multidimensional overview of in-port ship pollution, this study applied both EO and FC methods to figure out port emissions emitted in POI during 2019 with the activity time data collected from the VTS system. The methodology of the bottom-up approach was developed by improving the general estimation equations from the previous works, which are reviewed in the literature review. The total volume of emissions discharged from a ship call is the aggregation of emissions from the combustion of all engines operated in all activity phases. Then, emission results from calls were scaled up to reach the entire POI emission in 2019. Also, CF is used for adjusting emission factors, and in this study, CF will be assumed to be 1, meaning there are no emission reduction technologies installed on ships.

4.1. EO Method. EO method adheres to the generic equation mentioned in the literature review part. The energy demand here considers the energy output of the engine over the operating time. The equation for the EO method applied in this study considers all activity phases, air pollutants, and engines in a ship call as follows:

$$
E_{s, i}=\sum_{\mathrm{ph}, j}\left[T_{s, p h} \sum_{j}\left(P_{s, j} \times \mathrm{LF}_{s, j} \times \mathrm{EF}_{i, j, \mathrm{ph}}\right)\right],
$$

where $E$ represents the total volume of emission emitted over a complete ship call (g); $T$ represents activity time (hour); $P$ represents engine power $(\mathrm{kW})$; LF represents load factor (\%); EF represents emission factor $(\mathrm{g} / \mathrm{kWh}) ; s$ represents ship call; $i$ represents pollutant; ph represents the activity phase of a ship call (hotelling at anchorage, cruising, maneuvering, and hotelling at berth); and $j$ represents engine type (propulsion engine and auxiliary engine).

The propeller law is applied to calculate the propulsion engine load factor $\left(\mathrm{LF}_{m}\right)$, as shown in the following equation:

$$
\mathrm{LF}_{m}=\left(\frac{\mathrm{AS}}{\mathrm{MS}}\right)^{3}
$$

where AS = ship actual speed (knots) and MS = ship maximum speed (knots), which is defined by the manufacturer. In the case of the auxiliary engine load factor $\left(\mathrm{LF}_{a}\right)$, because 
TABLE 2: Summary of POI’s capacity. Source: [79].

\begin{tabular}{|c|c|c|c|c|c|c|c|}
\hline \multicolumn{8}{|c|}{ Handling Capacity } \\
\hline No. & Port & $\begin{array}{l}\text { Max. Ship } \\
\text { DWT }\end{array}$ & Berths & $\begin{array}{l}\text { Berth length } \\
\quad(\mathrm{m})\end{array}$ & $\begin{array}{c}\text { Bulk } \\
(1000 \mathrm{RT})\end{array}$ & $\begin{array}{l}\text { Container } \\
\text { (1000TEU) }\end{array}$ & Main products \\
\hline 1 & Inner Port & 50,000 & 46 & 9,838 & 38,161 & & General cargo, iron, grains \\
\hline 2 & South Port & 100,000 & 25 & 3,642 & 17,600 & 762 & Chemical, cement, sand \\
\hline 3 & Coastal Port & 50,000 & 9 & 1,429 & & & Passenger, oil, LPG \\
\hline 4 & North Port & 100,000 & 26 & 6,421 & 13,900 & & $\begin{array}{l}\text { Oil, general cargo, wood } \\
\text { product }\end{array}$ \\
\hline 5 & New Port & 3,000 & 6 & 1,600 & & 2,100 & Container \\
\hline 6 & Song-do & 75,000 & 4 & 1,300 & & & LPG, oil \\
\hline 7 & $\begin{array}{l}\text { Yeongheung- } \\
\text { do }\end{array}$ & 200,000 & 5 & 1,126 & 14,690 & & Bituminous coal, limestone \\
\hline 8 & Geocheom-do & 5,000 & 4 & 675 & 8,320 & & Sand \\
\hline Summary & & 125 & 26,031 & 92,671 & 2,862 & $28,735.5$ & \\
\hline
\end{tabular}

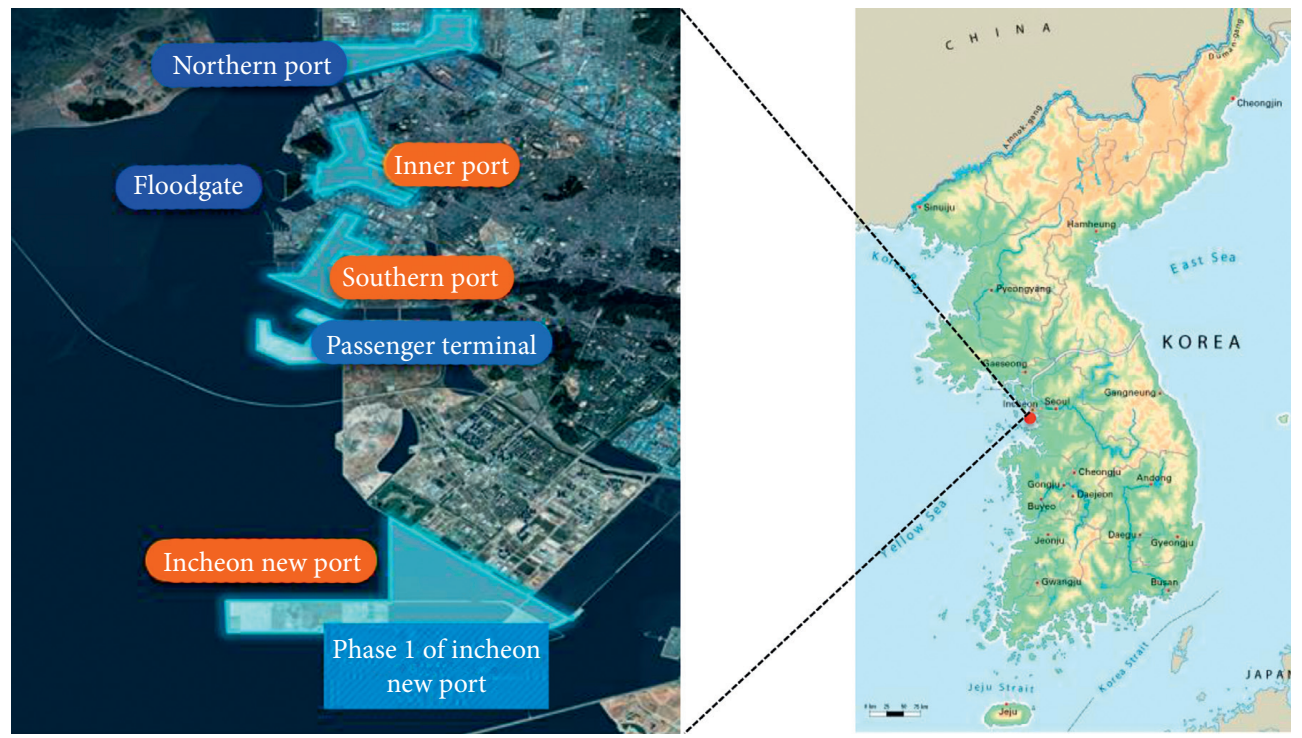

Figure 1: Geographical segments of Port of Incheon. Note: images were downloaded from the Internet and Incheon Port Authority (IPA) website.

TABle 3: Ship activity segments and features in POI.

\begin{tabular}{ccccccc}
\hline & Phase category & Propulsion engine & Auxiliary engine & Boiler & Avg. speed (knots) & Travel distance (nm) \\
\hline 1 & Hotelling at anchorage & Off & On & On & 0 & 0 \\
2 & Cruising & On & On & Off & 12 & Varies by berth \\
3 & Maneuvering & On & On & On & Around 3.5 & 1 \\
4 & Hotelling at berth & Off & On & On & 0 & 0 \\
\hline
\end{tabular}

it varies by ship type and activity phases, and the data sources are limited, therefore, ICF [30] also suggested default $\mathrm{LF}_{a}$ assumptions in his study. This study referred to these values for calculation.

The non- $\mathrm{CO}_{2}$ EFs used here were referred from Lee et al. [70]. For $\mathrm{CO}_{2}$ emission, the carbon fraction in the fuel used is defined at $86.8 \%$ by weight, and a factor of molecular weight of $\mathrm{C}$ and $\mathrm{CO}_{2}$ equals 44/12. Using SFCs referred from ICF [30], the EFs for $\mathrm{CO}_{2}$ emission are calculated as

$$
\mathrm{CO}_{2} \mathrm{EF}=0.868 \cdot \frac{44}{12} \text {. SFC. }
$$

As an international hub port, most ships visited POI are defined as international ocean-going ships; therefore, international EFs estimation methods suggested in them are deemed adaptable for this study. Applied EFs in the EO method are summarized in Table 9.

4.2. FC Method. Similar to the EO method, the FC method's equation adheres to the generic equation and considers fuel consumption of the engine over the operating time to figure out energy demand. The detailed equation for fuel consumption applied in this study is referred from Corbett et al. 
TABLe 4: Ship call statistics (unit: ship call). Source: Port-MIS.

\begin{tabular}{|c|c|c|c|c|c|c|c|}
\hline Ship types & North Port & Inner Port & Coastal Port & South Port & New Port & Others & Total \\
\hline Bulk carrier & 253 & 304 & - & 104 & - & - & 661 \\
\hline Container ship & 27 & 13 & 7 & 968 & 1,871 & - & 2,886 \\
\hline Cruise ship & 6 & 3 & 6 & 7 & - & 1 & 23 \\
\hline General cargo & 1,056 & 696 & 149 & 1,406 & 47 & 20 & 3,374 \\
\hline RoRo & 2 & 777 & 738 & 330 & - & - & 1,847 \\
\hline Reefer & 2 & - & 1 & 1 & - & - & 4 \\
\hline Tanker & 4,144 & 473 & 639 & 836 & 165 & 847 & 7,104 \\
\hline Miscellaneous & 113 & 61 & 77 & 204 & 29 & 294 & 778 \\
\hline Total & 5,603 & 2,327 & 1,617 & 3,856 & 2,112 & 1,162 & 16,677 \\
\hline
\end{tabular}

[31]; then, the final equation for the FC method is formed and shown in the following equation:

$$
\begin{aligned}
E_{s, i, p h} & =\sum_{\mathrm{ph}, j} \mathrm{FC}_{\mathrm{ph}, j} \times \mathrm{EF}_{j, i, \mathrm{ph}} \\
& =\sum_{\mathrm{ph}}\left\{T_{\mathrm{ph}} \times\left[\mathrm{MF}_{\mathrm{ph}} \times\left(\frac{\mathrm{AS}}{\mathrm{MS}}\right)^{3} \times \mathrm{EF}_{m, i, \mathrm{ph}}+\mathrm{AF}_{\mathrm{ph}} \times \mathrm{EF}_{a, i, \mathrm{ph}}\right]\right\} .
\end{aligned}
$$

\section{Results and Discussion}

This section reports a multidimensional bottom approach inport ship emission inventory in POI during 2019, including two inventories estimated under the two methods mentioned above. These inventories figured out in-port ship emissions in seven geographical segments (at sea, five main ports, and other specialized ports), by eight types of air pollutants and by four ship activity phases. There was considerable variance between results from the two methods. EO method reported 201,612.26 tonnes of $\mathrm{CO}_{2}, 323.85$ tonnes of $\mathrm{CO}, 4,097.79$ tonnes of $\mathrm{NO}_{x}, 1,237.92$ tonnes of $\mathrm{SO}_{x}, 145.06$ tonnes of PM10 (including PM2.5), 133.32 tonnes of PM2.5, 136.21 tonnes of VOCs, and 0.44 tonne of $\mathrm{NH}_{3}$, while FC method showed 193,981.71 tonnes, 452.88 tonnes, 3,573.27 tonnes, 1,224.01 tonnes, 88.21 tonnes, 82.33 tonnes, 116.09 tonnes, and 0.43 tonne, respectively. The total fuel consumption for ships at POI during 2019 (reported in FC method) was nearly 61,193 tonnes.

In general, the EO method reported higher values than the FC method's value with almost all pollutants, except for $\mathrm{CO}$ emissions. Also, there are big gaps (in percentage) between the calculated volumes of $\mathrm{NO}_{x}, \mathrm{CO}$, and PM emissions of the two inventories. However, both inventories mutualized in the rank of emitted pollutants in POI's emission inventory. $\mathrm{CO}_{2}$ was the dominating air pollutant in both inventories at POI during 2019, accounting for about $97 \%$ of the total amount of emitted emissions. Among the rest, $\mathrm{NO}_{x}$ was the most serious air pollutant in both inventories at POI during 2019, which covers over $64 \%$ of the total amount of non- $\mathrm{CO}_{2}$ emissions, followed by $\mathrm{SO}_{x}$ emissions with over $20 \%$. The contribution of CO ranged from $5-8 \% . \mathrm{NH}_{3}$ just accounted for nearly $0.01 \%$ of the total amount of non- $\mathrm{CO}_{2}$ emissions. Other pollutants' shares in both inventories were also insignificant with less than $2.5 \%$ of the total non- $\mathrm{CO}_{2}$ volume. The comparison of $\mathrm{EO}$ with $\mathrm{FC}$ methods about non- $\mathrm{CO}_{2}$ emissions is shown in Figure 3.

Figure 4 presents the inventories of ship emission by geographical areas during 2019, considering the sea area (when ships moved on the area of the sea from affected zone to berths) and port areas (when ships docked at berths, involving five main component ports and three others). Both inventories agreed that almost all ship emissions were exhausted on sea area. Also, the big difference between the two inventories happened in sea area (7\%), while they showed similar volumes at berths. The emission share on sea area is $53-55 \%$ of the total amount of emissions. Among port areas, Inner Port was the most polluted port, accounting for $14 \%$ of the ship emissions, followed by North Port and South Port with a ratio of $9 \%$ and $7 \%$, respectively. Coastal Port shared the smallest proportion, compared to five main component ports, with almost $4 \%$ of the total amount of emission.

The great contribution of Inner Port, North Port, and South Port to the air pollution at POI has been anticipated because they are the most important and busiest ports at POI. With a lock-gate, the Inner Port is the ideal port for handling car ferries; therefore, the RORO fleet (mainly car ferries) supplies mainly for the first rank of Inner Port. The tanker fleet was distributed in all ports of POI; however, the concentration in a large number of tankers in North Port pushed it to become the second polluted port at POI. In the case of South Port, general cargo and container ship fleets are the main emission contributors there.

Next, Figure 5 illustrates the emission contribution by ship types at POI during 2019. Tanker fleet was agreed as the most polluted fleet at POI, with around $29 \%$ of total in-port emission volume, followed by general cargo, RORO, and container ship. However, two inventories show a dissimilar view in the ranks of these three groups. While EO inventory reports that second rank belongs to container ship fleet, which contributed up to $20.1 \%$ of emission volume, followed closely by RORO fleet and general cargo fleet with the ratio of $19.8 \%$ and $19.6 \%$, respectively; in case of FC inventory, the RORO fleet raised to occupy the second position with $20.3 \%$, pushed general cargo fleet down to the third rank with $19.8 \%$, and container ship fleet only contributed $19.7 \%$ of the total amount of emissions, ranked fourth. The top- 4 polluted fleets supplied $88.7 \%$ of the total emission volume. In both inventories, the bulk carrier fleet also was a considerable polluted source, which contributed over $8.8 \%$ of the total 

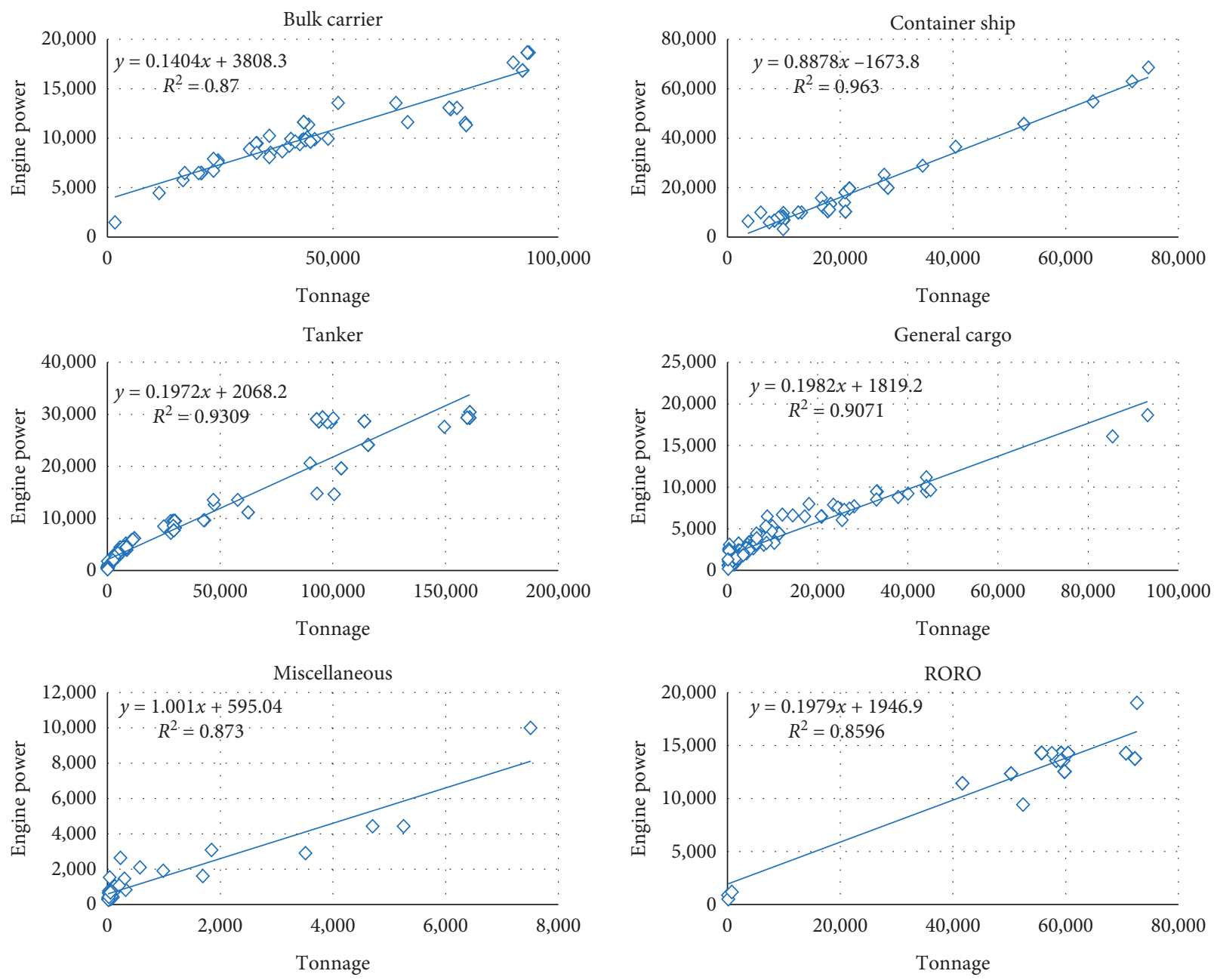

FIGURE 2: Linear regression of missing main engine data by ship type.

TABle 5: The ratio for estimating auxiliary engine power. Source: ICF [30].

\begin{tabular}{lc}
\hline Ship type & Auxiliary to propulsion ratio \\
\hline Bulk carrier & 0.222 \\
Container ship & 0.220 \\
Cruise ship & 0.278 \\
General cargo & 0.191 \\
RORO & 0.259 \\
Reefer & 0.406 \\
Tanker & 0.211 \\
Others & 0.100 \\
\hline
\end{tabular}

amount of emission, ranked fifth. Other fleets present minor contributions, fewer than $2 \%$. Therefore, IPA should focus on emission reduction from tanker, general cargo, RORO, and container ship.

Then, Figure 6 shows ship emission inventories by activity phases. Although the rankings and contribution (in percentage) of cruising and hotelling at berth are interchanged in two inventories, however, it is undeniable that they overshadowed others in total emitted emissions. During hotelling at berth, the propulsion engine is in respite, and then auxiliary engines monopolize in emitting all emissions.
Therefore, besides the implementation of ECA, to reduce the volume of in-port ship emissions, efforts to cut down emissions during cruising and hotelling at berth phases are indispensable.

\section{Ship-Related Emissions Reduction Policies at POI}

As discussed above, several policies are designed to reduce the volume of emissions emitted from ships operated at POI as (1) local ECA realization, (2) VSR program motivation, (3) application of cold ironing, and (4) establishment of a national integrated emission platform. In this study, the above-calculated EO emission inventory is adopted as the baseline emission inventory and solutions (1)-(3) are simulated and evaluated based on EO method if assuming that these suggested policies are applied at POI. The potential benefit of solution (4) also is discussed.

6.1. Assessing the Environmental Benefit of Designating the Local ECA. The great contribution of $\mathrm{NO}_{x}$ and $\mathrm{SO}_{x}$ emissions among non- $\mathrm{CO}_{2}$ emissions to air pollution at POI suggests the necessity of designating a local $\mathrm{NO}_{x}$ and $\mathrm{SO}_{x}$ 
TABLE 6: Average RPM values.

\begin{tabular}{lcc}
\hline Ship type & Average RPM values of propulsion engines & Average RPM values of auxiliary engines \\
\hline Bulk carrier & 103 & 843 \\
Container ship & 131 & 847 \\
Cruise ship & 484 & 895 \\
General cargo & 271 & 1,225 \\
RoRo & 105 & 787 \\
Reefer & 311 & 1,043 \\
Tanker & 286 & 1,147 \\
Miscellaneous & 490 & 1,037 \\
\hline
\end{tabular}

TABle 7: Average transit time in POI 2019 (unit: hour).

\begin{tabular}{lc}
\hline Port & Average transit time \\
\hline North Port & 2.2 \\
Inner Port & 3.0 \\
Coastal Port & 1.6 \\
South Port & 1.7 \\
New Port & 1.4 \\
Song-do Port & 1.4 \\
Geocheom-do Port & 2.5 \\
Yeongheung-do Port & 0.75 \\
\hline
\end{tabular}

emission control area (ECA). In ECA, ships will be required to follow strictly Tier III in Regulation 13 of Annex VI of MARPOL 73/78 about reducing $\mathrm{NO}_{x}$ emissions and the sulphur contents in the fuel used will be reduced to $0.1 \%$. This idea was suggested firstly by Chang et al. [49]; however, it has not been implemented yet in Incheon or any other Korean ports. As of 2019, the required fuel used inside the POI area was MGO with the maximum sulphur content at $1.0 \%$ by mass. Then, with $\mathrm{SO}_{x} \mathrm{ECA}$, ships have to switch from high sulphur content fuel (1.0\%) to a very lower one $(0.1 \%)$. Assuming that energy efficiency is unchanged, since the volumes of $\mathrm{SO}_{x}$ and $\mathrm{PM}$ emissions released are dependent critically on the sulphur content in the fuel used according to estimating equations applied in Lee et al. [70], the $\mathrm{SO}_{x}$ ECA could help decrease 10 times the amount of $\mathrm{SO}_{x}$ emission and nearly 2.5 times the amount of PM emission. The cutdown volume of emissions will be 1114.12 tonnes of $\mathrm{SO}_{x}$ and 71.07 tonnes of PM10 (including 65.25 tonnes of PM2.5) if the $\mathrm{SO}_{x}$ ECA is established.

Different from $\mathrm{SO}_{x}$ emission, in the case of $\mathrm{NO}_{x}$ emission, the abatement is implemented mostly by technology improvement in the engine's combustion and selective catalytic reduction (SCR) system equipped onboard. Due to the limitation of the estimating method, it is difficult to simulate and estimate the expected reduction in $\mathrm{NO}_{x}$ emission; therefore, the reduction of $\mathrm{NO}_{x}$ is not considered in this study.

6.2. Assessing the Environmental Benefit of the VSR Program. In the last few days of December 2019, the Korean Ministry of Oceans and Fisheries started designating the "Vessel Speed Reduction Program" in five Korean main ports, including POI, to lessen PM levels during winter. Ships are motivated to transit slower than certain speeds (12 knots for container ships and car-carriers and 10 knots for others). To facilitate the analysis, it is assumed that there was no RSZ in POI during 2019 when calculating the baseline emission inventory and then simulating the effect of RSZ if it is designated. With lower cruising speed (10 knots), the ships will take more cruising time but lower load factor for propulsion engines (see equation (6)). Then, an RSZ can help reduce 7-8\% amount of each pollutant: 22.77 tonnes of CO, 295.83 tonnes of $\mathrm{NO}_{x}, 87.03$ tonnes of $\mathrm{SO}_{x}, 10.45$ tonnes of PM10 (including 9.61 tonnes of PM2.5), 11.15 tonnes of VOC, 0.03 tonne of $\mathrm{NH}_{3}$, and 14,167.93 tonnes of $\mathrm{CO}_{2}$.

6.3. Assessing the Environmental Benefit of Applying Cold Ironing. In the case of hotelling at berth, emission could be cut down through reducing docking time or cut-downing emissions from docking time. In practice, reducing docking time is complicating and challenging because it is related to overhauling, optimizing, and scheduling the operation of a chain including other port facilities such as quay cranes, internal trucks, and yard cranes. In contrast, reducing emissions from docking time could be achieved easily by using an on-shore power supply. Assuming that 50\% of hotelling time in each port is applied this technology, it will help reduce $22-23 \%$ amount of each pollutant: 72.26 tonnes of CO, 913.14 tonnes of $\mathrm{NO}_{x}, 278.54$ tonnes of $\mathrm{SO}_{x}, 32.19$ tonnes of PM10 (including 29.56 tonnes of PM2.5), 27.59 tonnes of VOC, 0.1 tonne of $\mathrm{NH}_{3}$, and 45,375.03 tonnes of $\mathrm{CO}_{2}$.

If three of them are conducted together, this will help cut down 95.03 tonnes of CO, 1208.97 tonnes of $\mathrm{NO}_{x}, 1150.68$ tonnes of $\mathrm{SO}_{x}, 92.51$ tonnes of PM10 (including 84.97 tonnes of PM2.5), 38.74 tonnes of VOC, 0.13 tonne of $\mathrm{NH}_{3}$, and $59,542.96$ tonnes of $\mathrm{CO}_{2}$ corresponding to $29 \%, 30 \%, 93 \%$, $64 \%$ (64\%), $28 \% .30 \%$ and $30 \%$ of the total emitted amount of each pollutant in the 2019 baseline inventory.

\subsection{Establishment of a National Integrated Emission Platform.} Besides counter-measures, a good assessment and management system is indispensable for managing green reform at ports. With the widespread Internet, the combination of the platform industry and assessments of environmental situations around seaport would be an interesting and promising research topic shortly. With the platform, users can access and interact with the system actively and easily. This study suggests an idea about a national integrated platform that can standardize and systematize procedures in 
TABle 8: Average time in hotelling at anchorage and berth in POI 2019 (unit: hour).

\begin{tabular}{lcc}
\hline Types of ship & Average time in hotelling (hour) & Compare to the national avg. time in CAPSS (\%) \\
\hline Bulk carrier & 83.3 & 439.3 \\
Container ship & 13.6 & 71.7 \\
Cruise Ship & 50.3 & 265.3 \\
General cargo & 39.9 & 210.4 \\
RORO & 25.9 & 136.6 \\
Reefer & 89.0 & 469.4 \\
Tanker & 22.0 & 116.0 \\
Miscellaneous & 51.9 & 273.7 \\
\hline
\end{tabular}

TABle 9: Applied EFs for EO method (unit: g/kWh). Source: Lee et al. [70].

\begin{tabular}{lcccccccccc}
\hline Engine type & Phase & $\mathrm{CO}$ & $\mathrm{CO}_{2}$ & $\mathrm{NO}_{x}$ & $\mathrm{SO}_{x}$ & $\mathrm{PM} 10$ & $\mathrm{PM} 2.5$ & $\mathrm{VOCs}$ & $\mathrm{NH}_{3}$ & $\mathrm{BSFC}^{2}$ \\
\hline Propulsion-HSD & Cruising & 1.1 & 646.14 & 12.0 & 3.97 & 0.47 & 0.43 & 0.21 & 0.0014 & 203 \\
Propulsion-MSD & Cruising & 1.1 & 646.14 & 13.2 & 3.97 & 0.47 & 0.43 & 0.63 & 0.0014 & 203 \\
Propulsion-SSD & Cruising & 0.5 & 588.85 & 17.0 & 3.62 & 0.45 & 0.42 & 0.53 & 0.0013 & 185 \\
Propulsion-HSD & Maneuvering & 2.2 & 709.8 & 9.6 & 4.36 & 0.50 & 0.46 & 0.63 & 0.0016 & 223 \\
Propulsion-MSD & Maneuvering & 2.2 & 709.8 & 10.6 & 4.36 & 0.50 & 0.46 & 1.58 & 0.0016 & 223 \\
Propulsion-SSD & Maneuvering & 1.0 & 649.32 & 13.6 & 3.99 & 0.47 & 0.44 & 1.90 & 0.0014 & 204 \\
Auxiliary & All & 1.1 & 690.71 & 13.9 & 4.24 & 0.49 & 0.45 & 0.42 & 0.0015 & 217 \\
\hline
\end{tabular}

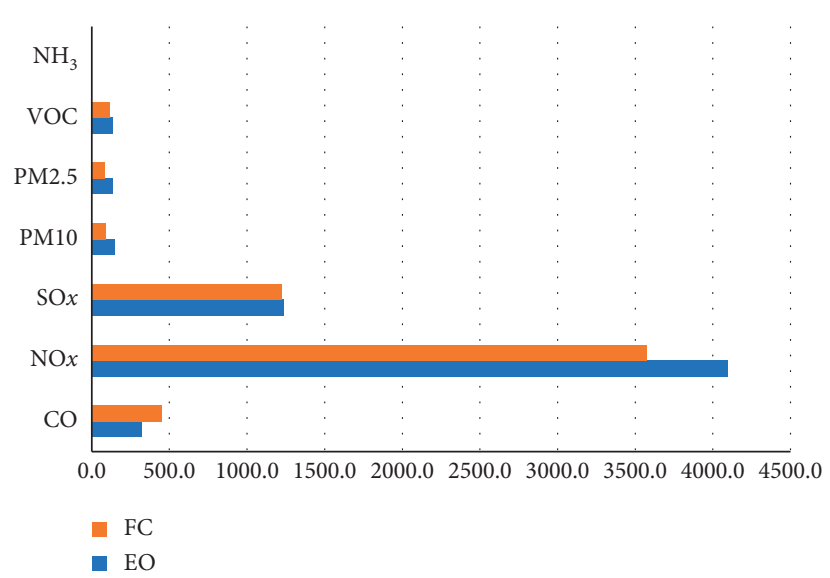

Figure 3: Non- $\mathrm{CO}_{2}$ emissions comparison between FC and EO methods (unit: tonnes).

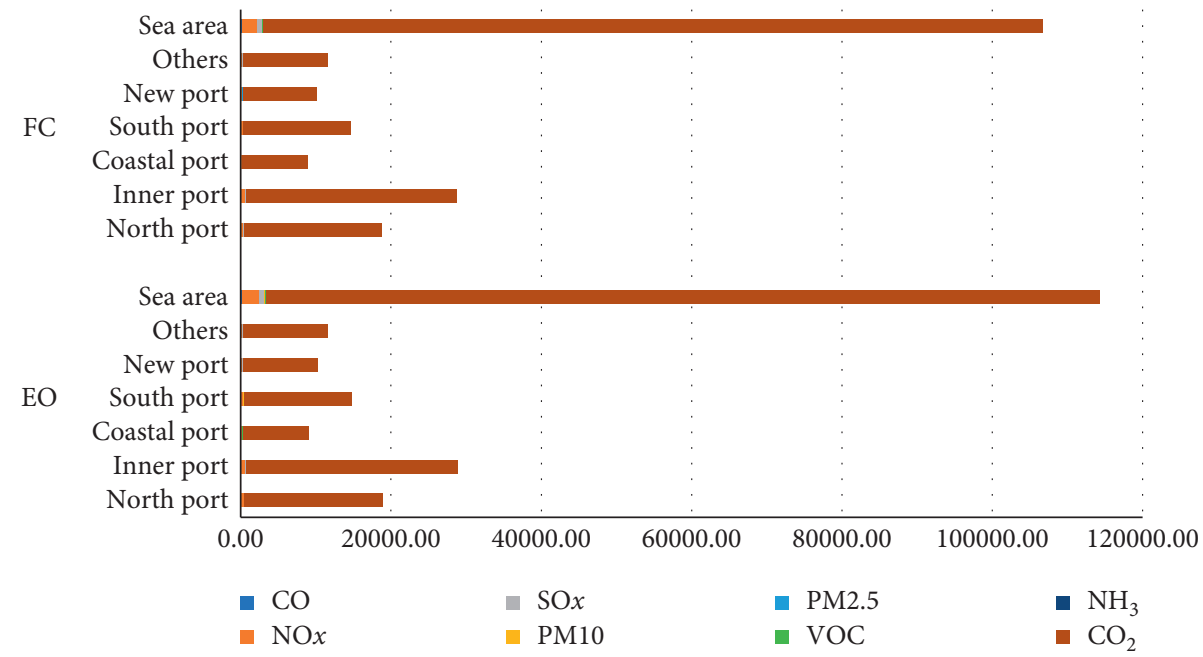

Figure 4: POI 2019 ship emission inventories by geographical areas (Unit: tonnes). 


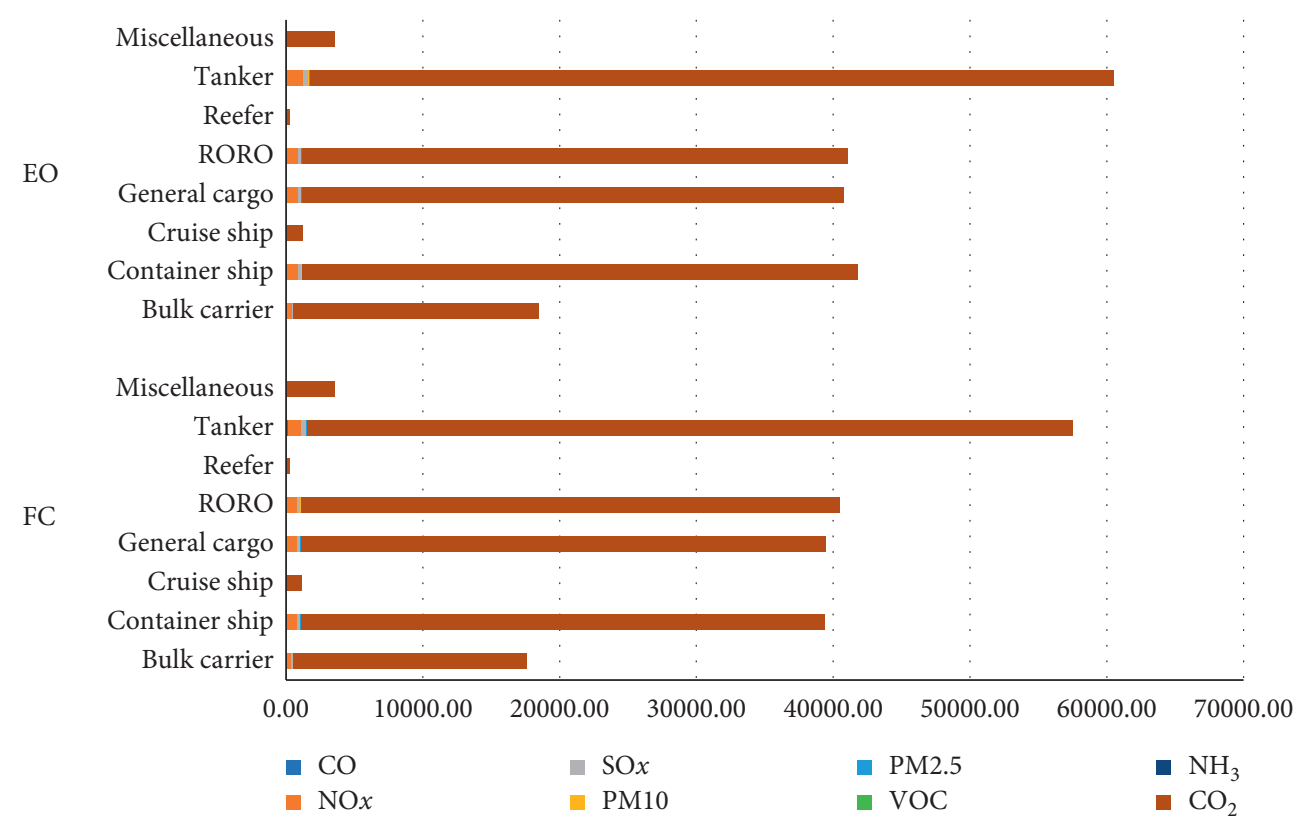

Figure 5: POI 2019 ship emission inventory by ship type (unit: tonnes).

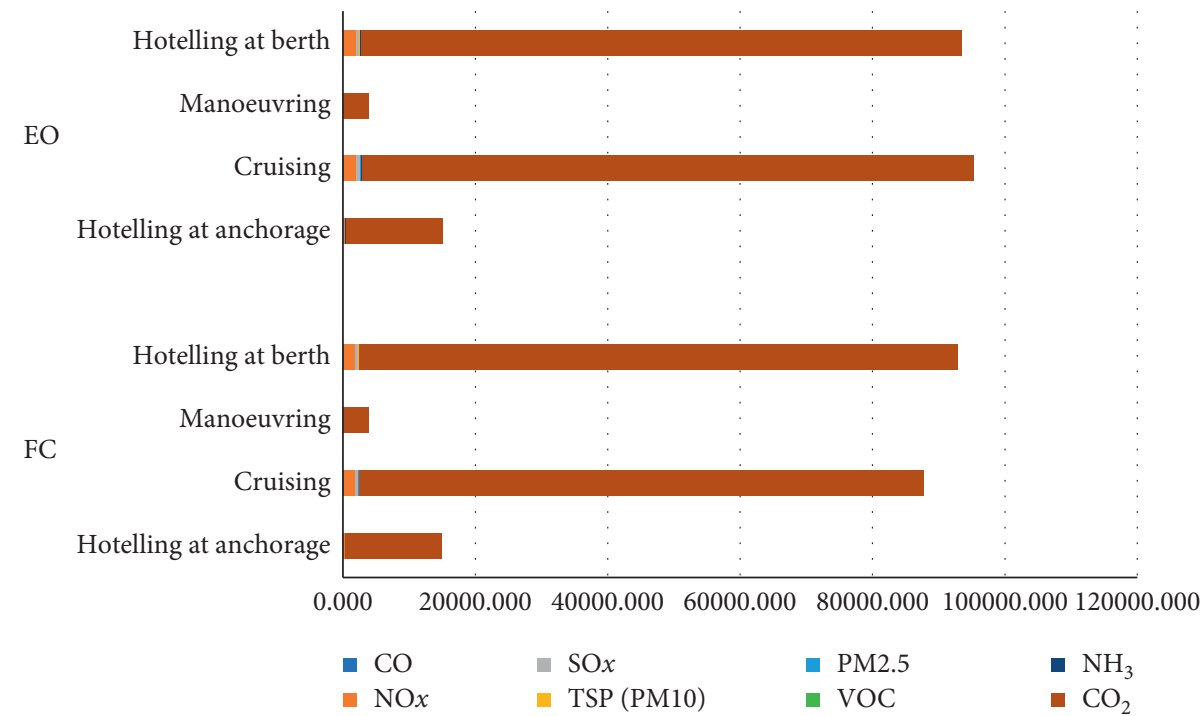

FIgURE 6: POI 2019 ship inventory by ship activity phase (unit: tonnes).

monitoring harmful ship-related emissions released from ports in Korea. This platform will provide three main functions: (1) data collection and analysis; (2) estimation, modification, and visualization; and (3) prediction. The abovementioned three functions are proposed to ensure and emphasize the systematicness to generate a better air pollutant assessment and management.

The necessary input data for emission estimation is linked with and automatic-synchronized simultaneously from the national Port-MIS system. Then, based on collected data, the system analyses, estimates, and visualizes the volume of emissions emitted or environment indexes promptly to warn the port operator if the negative impacts on the local community from in-port emissions exceed a certain "safe" level. Then, input data adjustment in the modification function allows port operators to adjust or reschedule the port operation, through suppositions and corresponding input adjustment, to reduce geographic emissions to the "safe" level. Also, by machine-learning algorithms and statistical analyses, the prediction function helps port operators predict the trend of air pollution at ports and then plan port operations appropriately. Also, the researchers use modification and prediction function in annual or seasonal emission inventory with their recommended air management policies or counter-measures to assess the performances of them. 


\section{Conclusion}

As a result of the quick spreading of global trade, atmospheric pollution from transportation has been more topical than ever, especially in dense hub port-cities. Given environmental legislation that is enforced currently, the shipping industry has not been paid adequate attention to its relatively considerable volume of emitted emissions. Besides published national reports, the awareness of atmospheric pollution from growing port traffic has invoked reliable and upto-date regional comprehensive assessments of egregious environmental impacts from in-port ship traffic with timely counter-measures. This study contributes to the stream of in-port ship emission research both theoretically and practically. Besides the sole application of AIS for inputs in the bottom-up approach studies, VTS could be considered as a promising confident alternative. In Korea, with support from the government, the VTS-based Port-MIS system would be a reliable data source for local studies.

This study generated a comprehensive annual ship emission inventory at POI in 2019, according to geographical areas, operational phases, and ship types by the bottom-up approach. Although there are small differences between the results of the two methods EO and FC, and it is impossible to demonstrate which one is better, however, two inventories agree about the dominance of $\mathrm{CO}_{2}$ emission and the considerable volume of $\mathrm{NO}_{x}$ and $\mathrm{SO}_{x}$ emissions in the total volume of port emissions, the significant contribution of auxiliary engines during hotelling at berth phase and the 4-most polluted ship types at POI during the year of 2019. Also, this study suggests and simulates the effects of four applicable green policies for the POI situation in the practice. The combination of the three abovementioned policies could help slash the significant volume of emitted CO (29\%), $\mathrm{NO}_{x}$ (30\%), $\mathrm{SO}_{x}$ (93\%), PM10 and PM2.5 (64\%), VOC (28\%), $\mathrm{NH}_{3}(30 \%)$, and $\mathrm{CO}_{2}(30 \%)$.

Given most ships visited POI could be considered as international waterborne navigation, using default inputs in the estimation process (e.g., EF, auxiliary characteristics data, and engine load factor), that referred from international studies, is deemed acceptable. Moreover, boilers also were not collected completely and considered because there is a lack of information from manufacturers and ship owners. Therefore, for better estimation, the authors also recommend the adoption of local values to reduce uncertainty. However, currently, Korean data are limited; therefore, it garners the attention of investigating local-specific inputs. Moreover, an idea of the automatic input collecting system be synchronized with our proposed integrated system could be another interesting topic for further research.

Although both inventories also reported an insignificant volume of PM emissions, in terms of weight contribution, however, if compared their size and weight to other pollutants, they would be a potential threat to the port environment as well as the local community. Therefore, besides figuring out the weight of the total volume of PM emitted, the evaluation of spatial seasonal PM dispersion in the port area would be extremely necessary. This evaluation will contribute considerably to ship emission inventory and the deep understanding of the affection of in-port ship PM emissions.

Finally, the port operation also contains other important activities with various types of cargo handling equipment, railcars, and drayage trucks, and they contribute significantly to port pollution. Therefore, a broader view of a comprehensive in-port emission inventory or a port-scale integrated system, which presents emissions not only from ships but also from other port-related land-based vehicles, should be considered soon to understand completely about port pollution. Of course, this complete inventory would be a great baseline for other in-port environment evaluating studies in Incheon as well as other similar regions.

\section{Data Availability}

Data are available from Port-MIS (https://new.portmis.go. kr/portmis) operated by Ministry of Oceans and Fisheries.

\section{Conflicts of Interest}

The authors declare that there are no conflicts of interest regarding the publication of this paper.

\section{Acknowledgments}

This work was supported by an Incheon National University Research Grant in 2020.

\section{References}

[1] Y. Kwon, H. Lim, Y. Lim, and H. Lee, "Implication of activitybased vessel emission to improve regional air inventory in a port area," Atmospheric Environment, vol. 203, pp. 262-270, 2019.

[2] S. Song, "Ship emissions inventory, social cost and eco-efficiency in Shanghai Yangshan port," Atmospheric Environment, vol. 82, pp. 288-297, 2014.

[3] J. H. J. Hulskotte and H. A. C. Denier van der Gon, "Fuel consumption and associated emissions from seagoing ships at berth derived from an on-board survey," Atmospheric Environment, vol. 44, no. 9, pp. 1229-1236, 2010.

[4] K. Cullinane and S. Cullinane, "Atmospheric emissions from shipping: the need for regulation and approaches to compliance," Transport Reviews, vol. 33, no. 4, pp. 377-401, 2013.

[5] M. C. Sanabra, J. J. Usabiaga Santamaría, and F. X. Martínez De Osés, "Manoeuvring and hotelling external costs: enough for alternative energy sources?" Maritime Policy \& Management, vol. 41, no. 1, pp. 42-60, 2014.

[6] O. Merk, Shipping Emissions in Ports (Discussion Paper No. 2014-20), International Transport Forum, Paris, France, 2014.

[7] F. Alver, B. A. Saraç, and Ü. Alver Şahin, "Estimating of shipping emissions in the samsun port from 2010 to 2015," Atmospheric Pollution Research, vol. 9, no. 5, pp. 822-828, 2018.

[8] J. S. L. Lam and T. Notteboom, "The greening of ports: a comparison of port management tools used by leading ports in Asia and Europe," Transport Reviews, vol. 34, no. 2, pp. 169-189, 2014.

[9] L. Bilgili and U. B. Celebi, "Emission routing in maritime transportation," in Energy, Transportation and Global Warming, pp. 837-849, Springer, Cham, Switzerland, 2016. 
[10] J. S. Carlton, S. D. Danton, R. W. Gawen et al., Marine Exhaust Emissions Research Programme, Vol. 63, Lloyd's Register Engineering Services, London, UK, 1995.

[11] V. Eyring, H. W. Köhler, J. Van Aardenne, and A. Lauer, "Emissions from international shipping: 2. Impact of future technologies on scenarios until 2050," Journal of Geophysical Research, vol. 110, no. D17, 2005.

[12] European Environment Agency (EEA), EMEP/EEA Air Pollutant Emission Inventory Guidebook 2019 (Report No. 13/ 2019), Publications Office of the European Union, Luxembourg, UK, 2019.

[13] Natural Resources Defense Council, Harboring Pollution Strategies To CleanUp U.S. Ports, Natural Resources Defense Council, NewYork, NY, USA, 2004.

[14] J. J. Corbett, J. J. Winebrake, E. H. Green, P. Kasibhatla, V. Eyring, and A. Lauer, "Mortality from ship emissions: a global assessment," Environmental Science \& Technology, vol. 41, no. 24, pp. 8512-8518, 2007.

[15] International Maritime Organization, "Sulphur 2020-cutting Sulphur oxide emissions," 2020, http://www.imo.org/en/ MediaCentre/HotTopics/Pages/Sulphur-2020.aspx.

[16] European Union, "Directive (EU) 2016/802 of the European parliament and of the council of 11 May 2016 relating to a reduction in the sulphur content of certain liquid fuels," 2020, https://eur-lex.europa.eu/eli/dir/2016/802/oj.

[17] Environmental Protection Agency, "Control of emissions of air pollution from nonroad diesel engines and fuel; final rule," Federal Register, vol. 69, no. 124, pp. 38958-39273, 2004.

[18] "North China: emission control areas (update)," 2020, https:// www.nepia.com/industry-news/china-emission-controlareas-update/.

[19] European Environment Agency, Air Quality in Europe-2019 Report (Report No 10/2019), Publications Office of the European Union, Luxembourg, UK, 2019.

[20] International Institute for Applied Systems Analysis, "The potential for cost-effective air emission reductions from international shipping through designation of further emission control areas in EU waters with focus on the Mediterranean Sea," 2020, http://www.iiasa.ac.at/web/home/research/researchPrograms/ air/Shipping_emissions_reductions_main.pdf.

[21] Korea Ministry of Environment, Comprehensive Plan on Fine Dust Management, Korea Environmental Policy Bulletin, vol. 15, no. 2, Republic of Korea, 2018.

[22] Korean Ministry of Oceans and Fisheries, "Vessel speed reduction (VSR) program to start December this year," 2020, https://www.mof.go.kr/en/board.do?menuIdx=1491\&bbsIdx $=30629$.

[23] S.-K. Song and Z.-H. Shon, "Current and future emission estimates of exhaust gases and particles from shipping at the largest port in Korea," Environmental Science and Pollution Research, vol. 21, no. 10, pp. 6612-6622, 2014.

[24] A. Glowacz, "Fault diagnosis of single-phase induction motor based on acoustic signals," Mechanical Systems and Signal Processing, vol. 117, pp. 65-80, 2019.

[25] L. Huang, Y. Wen, X. Geng, C. Zhou, C. Xiao, and F. Zhang, "Estimation and spatio-temporal analysis of ship exhaust emission in a port area," Ocean Engineering, vol. 140, pp. 401-411, 2017.

[26] R. A. O. Nunes, M. C. M. Alvim-Ferraz, F. G. Martins, and S. I. V. Sousa, "The activity-based methodology to assess ship emissions - a review," Environmental Pollution, vol. 231, pp. 87-103, 2017.
[27] H. N. Psaraftis and C. A. Kontovas, " $\mathrm{CO}_{2}$ emission statistics for the world commercial fleet," WMU Journal of Maritime Affairs, vol. 8, no. 1, pp. 1-25, 2009.

[28] J. J. Corbett and H. W. Koehler, "Updated emissions from ocean shipping," Journal of Geophysical Research: Atmospheres, vol. 108, no. D20, 2003.

[29] A. Miola and B. Ciuffo, "Estimating air emissions from ships: meta-analysis of modelling approaches and available data sources," Atmospheric Environment, vol. 45, no. 13, pp. 2242-2251, 2011.

[30] ICF International, Current Methodologies in Preparing Mobile Source Port-Related Emission Inventories: Final Report, US Environmental Protection Agency (USEPA), Fairfax, VA, USA, 2009.

[31] J. J. Corbett, H. Wang, and J. J. Winebrake, “The effectiveness and costs of speed reductions on emissions from international shipping," Transportation Research Part D: Transport and Environment, vol. 14, no. 8, pp. 593-598, 2009.

[32] J. Joseph, R. S. Patil, and S. K. Gupta, "Estimation of air pollutant emission loads from construction and operational activities of a port and harbour in Mumbai, India," Environmental Monitoring and Assessment, vol. 159, no. 1-4, p. 85, 2009.

[33] C. Deniz and A. Kilic, "Estimation and assessment of shipping emissions in the region of Ambarlı Port, Turkey," Environmental Progress \& Sustainable Energy, 2009.

[34] C. Deniz, A. Kilic, and G. Civkaroglu, "Estimation of shipping emissions in Candarli gulf, Turkey," Environmental Monitoring and Assessment, vol. 171, no. 1-4, pp. 219-228, 2010.

[35] O. J. A. Howitt, V. G. N. Revol, I. J. Smith, and C. J. Rodger, "Carbon emissions from international cruise ship passengers' travel to and from New Zealand," Energy Policy, vol. 38, no. 5, pp. 2552-2560, 2010.

[36] A. Kiliç and C. Deniz, "Inventory of shipping emissions in izmit gulf, Turkey," Environmental Progress \& Sustainable Energy, vol. 29, no. 2, pp. 221-232, 2010.

[37] G. Lonati, S. Cernuschi, and S. Sidi, "Air quality impact assessment of at-berth ship emissions: case-study for the project of a new freight port," Science of the Total Environment, vol. 409, no. 1, pp. 192-200, 2010.

[38] E. Tzannatos, "Ship emissions and their externalities for the port of Piraeus-Greece," Atmospheric Environment, vol. 44, no. 3, pp. 400-407, 2010.

[39] K. Shin and J.-P. Cheong, "Estimating transportation-related greenhouse gas emissions in the Port of Busan, S. Korea," Asian Journal of Atmospheric Environment, vol. 5, no. 1, pp. 41-46, 2011.

[40] G. Villalba and E. D. Gemechu, "Estimating GHG emissions of marine ports-the case of Barcelona," Energy Policy, vol. 39, no. 3, pp. 1363-1368, 2011.

[41] C.-C. Chang and C.-M. Wang, "Evaluating the effects of green port policy: case study of Kaohsiung harbor in Taiwan," Transportation Research Part D: Transport and Environment, vol. 17, no. 3, pp. 185-189, 2012.

[42] J. Berechman and P.-H. Tseng, "Estimating the environmental costs of port related emissions: the case of Kaohsiung," Transportation Research Part D: Transport and Environment, vol. 17, no. 1, pp. 35-38, 2012.

[43] P. S. Yau, S. C. Lee, J. J. Corbett, C. Wang, Y. Cheng, and K. F. Ho, "Estimation of exhaust emission from ocean-going vessels in Hong Kong," Science of The Total Environment, vol. 431, pp. 299-306, 2012.

[44] Y.-T. Chang, Y. Song, and Y. Roh, "Assessing greenhouse gas emissions from port vessel operations at the Port of Incheon," Transportation Research Part D: Transport and Environment, vol. 25, pp. 1-4, 2013. 
[45] D. P. McArthur and L. Osland, "Ships in a city harbour: an economic valuation of atmospheric emissions," Transportation Research Part D: Transport and Environment, vol. 21, pp. 47-52, 2013.

[46] S. K. W. Ng, C. Loh, C. Lin et al., "Policy change driven by an AIS-assisted marine emission inventory in Hong Kong and the Pearl river delta," Atmospheric Environment, vol. 76, pp. 102-112, 2013.

[47] H. Saraçoğlu, C. Deniz, and A. Kılıç, "An investigation on the effects of ship sourced emissions in Izmir Port, Turkey," The Scientific World Journal, vol. 2013, Article ID 218324, 8 pages, 2013.

[48] H.-H. Tai and D.-Y. Lin, "Comparing the unit emissions of daily frequency and slow steaming strategies on trunk route deployment in international container shipping," Transportation Research Part D: Transport and Environment, vol. 21, pp. 26-31, 2013.

[49] Y.-T. Chang, Y. Roh, and H. Park, "Assessing noxious gases of vessel operations in a potential emission control area," Transportation Research Part D: Transport and Environment, vol. 28, pp. 91-97, 2014.

[50] T.-K. Liu, H.-Y. Sheu, and J.-Y. Tsai, "Sulfur dioxide emission estimates from merchant vessels in a port area and related control strategies," Aerosol and Air Quality Research, vol. 14, no. 1, pp. 413-421, 2014.

[51] L. Goldsworthy and B. Goldsworthy, "Modelling of ship engine exhaust emissions in ports and extensive coastal waters based on terrestrial AIS data-an Australian case study," Environmental Modelling \& Software, vol. 63, pp. 45-60, 2015.

[52] J. Coello, I. Williams, D. A. Hudson, and S. Kemp, “An AISbased approach to calculate atmospheric emissions from the UK fishing fleet," Atmospheric Environment, vol. 114, pp. 1-7, 2015.

[53] M. Tichavska and B. Tovar, "Port-city exhaust emission model: an application to cruise and ferry operations in Las Palmas Port," Transportation Research Part A: Policy and Practice, vol. 78, pp. 347-360, 2015.

[54] A. Maragkogianni, S. Papaefthimiou, and C. Zopounidis, Mitigating Shipping Emissions in European Ports: Social and Environmental Benefits, Springer International Publishing, Berlin, Germany, 2016.

[55] K. Cullinane, P.-H. Tseng, and G. Wilmsmeier, "Estimation of container ship emissions at berth in Taiwan," International Journal of Sustainable Transportation, vol. 10, no. 5, pp. 466-474, 2016.

[56] Q. Fan, Y. Zhang, W. Ma et al., "Spatial and seasonal dynamics of ship emissions over the Yangtze river delta and East China Sea and their potential environmental influence," Environmental Science \& Technology, vol. 50, no. 3, pp. 1322-1329, 2016.

[57] S. Papaefthimiou, A. Maragkogianni, and K. Andriosopoulos, "Evaluation of cruise ships emissions in the Mediterranean basin: the case of Greek ports," International Journal of Sustainable Transportation, vol. 10, no. 10, pp. 985-994, 2016.

[58] D. Chen, X. Wang, P. Nelson et al., "Ship emission inventory and its impact on the PM2.5 air pollution in Qingdao Port, North China," Atmospheric Environment, vol. 166, pp. 351-361, 2017.

[59] L. Styhre, H. Winnes, J. Black, J. Lee, and H. Le-Griffin, "Greenhouse gas emissions from ships in ports-case studies in four continents," Transportation Research Part D: Transport and Environment, vol. 54, pp. 212-224, 2017.

[60] V. Knežević, R. Radonja, and Č. Dundović, "Emission inventory of marine traffic for the port of Zadar," Pomorstvo, vol. 32, no. 2, pp. 239-244, 2018.
[61] S. Khan, Y.-T. Chang, S. Lee, and K.-S. Choi, "Assessment of greenhouse gas emissions from ships operation at the Port of Incheon using AIS," Journal of Korea Port Economic Association, vol. 34, no. 1, pp. 65-79, 2018.

[62] X. Sun, Z. Tian, R. Malekian, and Z. Li, "Estimation of vessel emissions inventory in Qingdao port based on big data analysis," Symmetry, vol. 10, no. 10, p. 452, 2018.

[63] Y.-L. Cao, X. Wang, C.-Q. Yin et al., "Inland vessels emission inventory and the emission characteristics of the beijinghangzhou grand canal in Jiangsu province," Process Safety and Environmental Protection, vol. 113, pp. 498-506, 2018.

[64] Y. Zhang, J. C. H. Fung, J. W. M. Chan, and A. K. H. Lau, "The significance of incorporating unidentified vessels into AISbased ship emission inventory," Atmospheric Environment, vol. 203, pp. 102-113, 2019.

[65] R. Ivce, A. Zekic, R. Radonja, and B. Reljac, "Emission inventory of ships calling at the port of Bršica (bay of Raša)," in Proceedings of the 2019 International Symposium ELMAR, Zadar, Croatia, September 2019.

[66] Z. Wan, Q. Zhang, Z. Xu, J. Chen, and Q. Wang, "Impact of emission control areas on atmospheric pollutant emissions from major ocean-going ships entering the Shanghai Port, China," Marine Pollution Bulletin, vol. 142, pp. 525-532, 2019.

[67] L. Stazić, R. Radonja, V. Pelić, and B. Lalić, "The port of Split international marine traffic emissions inventory," Pomorstvo, vol. 34, no. 1, pp. 32-39, 2020.

[68] Z. Wan, S. Ji, Y. Liu, Q. Zhang, J. Chen, and Q. Wang, "Shipping emission inventories in China's Bohai bay, Yangtze river delta, and pearl river delta in 2018," Marine Pollution Bulletin, vol. 151, Article ID 110882, 2020.

[69] A. Ekmekçioğlu, S. L. Kuzu, K. Ünlügençoğlu, and U. B. Çelebi, "Assessment of shipping emission factors through monitoring and modelling studies," Science of the Total Environment, vol. 743, Article ID 140742, 2020.

[70] H. Lee, D. Park, S. Choo, and H. T. Pham, "Estimation of the non-greenhouse gas emissions inventory from ships in the port of Incheon," Sustainability, vol. 12, no. 19, p. 8231, 2020.

[71] D. McCollum and C. Yang, "Achieving deep reductions in US transport greenhouse gas emissions: scenario analysis and policy implications," Energy Policy, vol. 37, no. 12, pp. 5580-5596, 2009.

[72] M. Tichavska and B. Tovar, "External costs from vessel emissions at port: a review of the methodological and empirical state of the art," Transport Reviews, vol. 37, no. 3, pp. 383-402, 2017.

[73] V. Eyring, I. S. A. Isaksen, T. Berntsen et al., "Transport impacts on atmosphere and climate: shipping," Atmospheric Environment, vol. 44, no. 37, pp. 4735-4771, 2010.

[74] L. Johansson, Emission Estimation of Marine Traffic Using Vessel Characteristics and AIS-Data, Aalto University, Espoo, Finland, 2011.

[75] National Institute of Environmental Research, National Air Pollutants Emission Service (in Korea), National Institute of Environmental Research, Incheon, South Korea, 2016, https:// airemiss.nier.go.kr/mbshome/mbs/airemiss/index.do.

[76] National Institute of Environmental Research, National Air Pollutant Emissions Handbook, National Institute of Environmental Research, Incheon, South Korea, 2020, https:// airemiss.nier.go.kr/user/boardList.do?command=view\&page =1\&boardId=85\&boardSeq=127\&id=airemiss_04020000000 0in Korea.

[77] National Institute of Environmental Research, Air Pollutants, National Institute of Environmental Research, Incheon, South Korea, 2020, http://airemiss.nier.go.kr/mbshome/mbs/ airemiss/subview.do?id=airemiss_020200000000In Korea. 
[78] American Association of Port Authorities, World Port Rankings 2016, American Association of Port Authorities, New York, NY, USA, 2020, https://www.aapa-ports.org/ unifying/content.aspx? ItemNumber=21048.

[79] Incheon Port Authority, "IPA introduction," https://www. icpa.or.kr/content/view.do?menuKey=114\&contentKey $=44$.

[80] Environmental Protection Agency, National Port Strategy Assessment: Reducing Air Pollution and Greenhouse Gases at U.S. Ports (EPA-420-R-16-011), Office of Transportation Air Quality, Washington, DC, USA, 2016. 